\title{
DNA Cleavage, Cytotoxic Activities, and Antimicrobial Studies of Ternary Copper(II) Complexes of Isoxazole Schiff Base and Heterocyclic Compounds
}

\author{
Vijay Kumar Chityala, ${ }^{1}$ K. Sathish Kumar, ${ }^{1}$ Ramesh Macha, ${ }^{2}$ \\ Parthasarathy Tigulla, ${ }^{2}$ and Shivaraj ${ }^{1}$ \\ ${ }^{1}$ Department of Chemistry, Osmania University, Hyderabad, Andhra Pradesh 500007, India \\ ${ }^{2}$ Department of Chemistry, University College of Science, Saifabad, Osmania University, Hyderabad, Andhra Pradesh 500004, India
}

Correspondence should be addressed to Shivaraj; shivaraj_sunny@yahoo.co.in

Received 31 October 2013; Accepted 7 January 2014; Published 8 May 2014

Academic Editor: Enrico Rizzarelli

Copyright ( $) 2014$ Vijay Kumar Chityala et al. This is an open access article distributed under the Creative Commons Attribution License, which permits unrestricted use, distribution, and reproduction in any medium, provided the original work is properly cited.

Novel mixed ligand bivalent copper complexes $\left[\mathbf{C u}\right.$. L. A. $\left.\mathbf{C l O}_{4}\right]$ and $[\mathbf{C u}$. L. A] where "L" is Schiff bases, namely 2-((3,4dimethylisoxazol-5-ylimino)methyl)-4-bromophenol (DMIIMBP)/2-((3,4-dimethylisoxazol-5-ylimino)methyl)-4-chlorophenol (DMIIMCP), and " $\mathrm{A}$ " is heterocyclic compound, such as 1,10 -phenanthroline (phen)/2,2 ${ }^{1}$-bipyridyl (bipy)/8-hydroxyquinoline (oxine)/5-chloro-8-hydroxyquinoline (5-Cl-oxine), have been synthesized. These complexes have been characterized by IR, UV-Vis, ESR, elemental analysis, magnetic moments, TG, and DTA. On the basis of spectral studies and analytical data, five-coordinated square pyramidal/four-coordinated square planar geometry is assigned to all complexes. The ligands and their ternary complexes with $\mathrm{Cu}(\mathrm{II})$ have been screened for antimicrobial activity against bacteria and fungi by paper disc method. The antimicrobial studies of Schiff bases and their metal complexes showed significant activity and further it is observed that the metal complexes showed more activity than corresponding Schiff bases. In vitro antitumor activity of $\mathrm{Cu}(\mathrm{II})$ complexes was assayed against human cervical carcinoma (HeLa) cancer cells and it was observed that few complexes exhibit good antitumor activity on HeLa cell lines. The DNA cleavage studies have also been carried out on pBR 322 and it is observed that these Cu(II) complexes are capable of cleaving supercoiled plasmid DNA in the presence of $\mathrm{H}_{2} \mathrm{O}_{2}$ and UV light.

\section{Introduction}

Heterocyclic moieties, found in large number of compounds, play an important role in several biological processes. The biological activity of these compounds is mainly dependent on their molecular structures [1-3]. The azomethine group in Schiff bases $(-\mathrm{N}=\mathrm{CH}-)$ is a significant feature that makes them important compounds owing to their wide range of biological activities [4-7]. Schiff bases are able to inhibit the growth of several animal tumors which can be altered depending upon the type of substituent present on the aromatic rings. Copper plays an essential role in the human organs and the function of copper in the human body is complex and not fully understood [8-11]. The role of Copper is a biocatalyst in the redox reactions. The $\mathrm{Cu}$ (II) complexes have demonstrated a wide variety of coordination geometries around $\mathrm{Cu}(\mathrm{II})$ atom with $\mathrm{N}, \mathrm{N}$ and $\mathrm{N}, \mathrm{O}$ donor ligands and the structure of complex depending on the number, type, and arrangement of ligands about the copper center. The ligands form stable five- or six-membered rings after complexation with the metal ion [12-15]. 8-Hydroxyquinoline and some of its derivatives are monoprotic $\mathrm{N}, \mathrm{O}$ donor bidentate chelating agents and exhibited substantial cytotoxic activity against cancer cells. The planar nature of "phen" is its ability to participate as either an intercalating or groove-binding agent with DNA [16-19].

The $\mathrm{Cu}(\mathrm{II})$ metal complexes may interact with DNA by covalent or noncovalent bindings. The labile part of these 
complexes is replaced by a nitrogen base of DNA such as guanine via its N7 donor atom. On other hand, the noncovalent DNA interactions include intercalative, electrostatic, and groove binding of cationic metal complexes along the outside of DNA helix. Intercalation involves the partial insertion of aromatic heterocyclic rings between the DNA base pairs. Copper has high Lewis acidity which eventually facilitates the DNA cleavage.

The interesting biological activities associated with Schiff bases and their mixed ligand complexes promoted us to investigate their DNA interactions. The present paper describes the synthesis, characterization, antimicrobial and antitumor activity, and DNA cleavage activity of novel ternary $\mathrm{Cu}(\mathrm{II})$ complexes $\left[\mathrm{Cu}(\mathrm{DMIIMBP})(\right.$ phen $\left.) \mathrm{ClO}_{4}\right](\mathbf{1})$, [Cu(DMIIMBP)(bipy) $\left.\mathrm{ClO}_{4}\right]$ (2), [Cu(DMIIMBP)(oxine)] (3), [Cu(DMIIMBP)(5-Cl-oxine)](4), [Cu(DMIIMCP)(phen ) $\left.\mathrm{ClO}_{4}\right](5),\left[\mathrm{Cu}(\mathrm{DMIIMCP})\left(\right.\right.$ bipy) $\left.\mathrm{ClO}_{4}\right](6),[\mathrm{Cu}(\mathrm{DMIIMCP})$ (oxine) $](7)$, and $[\mathrm{Cu}(\mathrm{DMIIMCP})(5$-Cl-oxine $)](8)$.

\section{Material and Methods}

2.1. Physical Measurements. ${ }^{1} \mathrm{H}-\mathrm{NMR}$ and ${ }^{13} \mathrm{C}$ - NMR spectra of the ligands were recorded on Bruker $400 \mathrm{MHz} \mathrm{NMR}$ instrument and using TMS as internal standard. The EI mass spectra were recorded on a VG micromass 7070$\mathrm{H}$ instrument; ESI mass spectra were recorded on VG AUTOSPEC mass spectrometer. Digital conductivity meter of model DI-909 having a dip-type cell was calibrated with $\mathrm{KCl}$ solution. Electronic spectra of metal complexes in DMSO were recorded on Schimadzu UV-VIS 1601 spectrophotometer. Magnetic susceptibilities of the complexes were determined on Gouy balance model 7550 using $\mathrm{Hg}\left[\mathrm{Co}(\mathrm{NCS})_{4}\right]$ as standard. The diamagnetic corrections of the complexes were computed using Pascal's constants. TG of complexes was carried on Mettler Toledo Star system in the temperature range of $0-1000^{\circ} \mathrm{C}$. Melting points of the ligands and decomposition temperature of complexes were determined on Polmon instrument (model number MP-96). IR spectra of the compounds were recorded using $\mathrm{KBr}$ pellets in the range $\left(4000-400 \mathrm{~cm}^{-1}\right)$ on Perkin-Elmer Infrared model 337. The percentage composition of $\mathrm{C}, \mathrm{H}$, and $\mathrm{N}$ of the compounds was determined by using microanalytical techniques on Perkin Elmer 240C (USA) elemental analyzer. The EPR spectra of the copper complexes were recorded on EPR Varian-E-112 at room temperature. The percentage composition of metal ions in solid metal complexes was determined by EDTA titration procedure. All the chemicals used were of analytical reagent grade. Solvents such as water, methanol, acetone, petroleum ether, and chloroform were purified by standard procedures [20].

\subsection{General Procedure for the Synthesis of Isoxazole Schiff} Bases. 3,4-Dimethyl-5-aminoisoxazole $(1.0 \mathrm{mmol})$ was dissolved in hot methanol to which 5-bromosalicylaldehyde/5chlorosalicylaldehyde $(1.0 \mathrm{mmol})$ was added and the mixture was refluxed for 2 hours under nitrogen atmosphere. The dark yellow product formed was filtered and washed with petroleum ether and recrystallized from methanol. Purity of the compounds checked by TLC showed single spot in petroleum ether and ethyl acetate $(6: 4)$ solvent mixture. Yield was $80-85 \%$.

2.3. Synthesis of Ternary Cu(II) Metal Complexes. The synthesis of copper complexes 1-8 was described in Scheme 1. In the preparation of metal complexes, metal to ligands ratio was maintained at $1: 1: 1$. Hot methanol solution of ligand $(1.0 \mathrm{mmol})$, hot methanol solution of copper acetate monohydrate $\left[\mathrm{Cu}\left(\mathrm{CH}_{3} \mathrm{COO}\right)_{2} \cdot \mathrm{H}_{2} \mathrm{O}\right](1.0 \mathrm{mmol})$, and methanol solution of 1,10 -phenanthroline $/ 2,2^{1}$-bipyridine/8hydroxyquinoline/5-chloro-8-hydroxyquinoline $(1.0 \mathrm{mmol})$ were mixed together with constant stirring. The mixture was refluxed for $2-3$ hours at $70-80^{\circ} \mathrm{C}$ on water bath. After cooling slowly, a few drops of $0.1 \mathrm{M} \mathrm{NaClO}_{4}$ were added for complexes $1,2,5$, and 6 with constant stirring over a period of $1 \mathrm{~h}$ and on cooling, the dark green/brown coloured metal complexes were precipitated. The products were filtered, washed with cold methanol, and dried under vacuum over $\mathrm{P}_{4} \mathrm{O}_{10}$.

2.4. Cell Culture. The human cervical carcinoma cell lines (HeLa) were cultured as a monolayer with Roswell Park Memorial Institute medium (RPMI-1640), supplemented with $10 \%$ (v/v) fetal bovine serum (FBS), 2 mM L-glutamine, $4.5 \mathrm{~g} / \mathrm{L}$ glucose, $1 \times$ nonessential amino acids, and $1 \times$ antibiotics consisting of penicillin/streptomycin, gentamycin, amphotericin $\mathrm{B}$, and nystatin at $37^{\circ} \mathrm{C}$, in a humidified atmosphere of $5 \% \mathrm{CO}_{2}$, in a $\mathrm{CO}_{2}$ incubator.

2.4.1. Cytotoxicity Assay (MTT Assay). The MTT assay was used to assess cytotoxicity [21]. The human cervical carcinoma cell lines (HeLa) were obtained from National Center for Cell Science (NCCS), Pune, India. Briefly, the copper complexes $(\mathbf{1}, \mathbf{2}, 5$, and 6) were dissolved in DMSO, diluted in culture medium, and used to treat the cancer cell, with the complex in the concentration range of 2 to $10 \mu \mathrm{g} / \mathrm{mL}$, for a period of $72 \mathrm{~h}$. DMSO diluted in the culture medium was used as the solvent control. A miniaturized viability assay using 3[4,5-dimethylthiazol-2-yl]-2,5-diphenyltetrazolium bromide (MTT) was carried out according to the method described earlier [22]. HeLa cells growing exponentially were added to 96-well plates (Orange Scientific) at a density of $3 \mathrm{x}$ 103 per well after counting on Bright Line Haemocytometer (Sigma Ltd.). Compounds $(2-10 \mu \mathrm{g} / \mathrm{mL})$ were then added to the wells, ensuring an equal volume of $200 \mu \mathrm{L}$ across the plates. Cytotoxicity/proliferation was measured at $72 \mathrm{~h}$ using a standard methyl thiazol tetrazolium (MTT) based assay without modifications. Briefly, MTT (Hi Media Ltd.) was added to each well to yield a working concentration of $0.4 \mathrm{mg} \mathrm{mL}^{-1}$, and the plates were returned to the incubator for a further $2 \mathrm{~h}$. After this time, the medium was aspirated, $200 \mu \mathrm{L}$ of DMSO (Sigma Ltd.) was then added to each well, and the plates were agitated gently for $5 \mathrm{~min}$ before measuring the optical density at $600 \mathrm{~nm}$ in each well using Thermo Scientific Multiskan EX Elisa reader. The $\mathrm{IC}_{50}$ value was determined as concentration of the complex that is required to reduce the absorbance to half that of the control. 


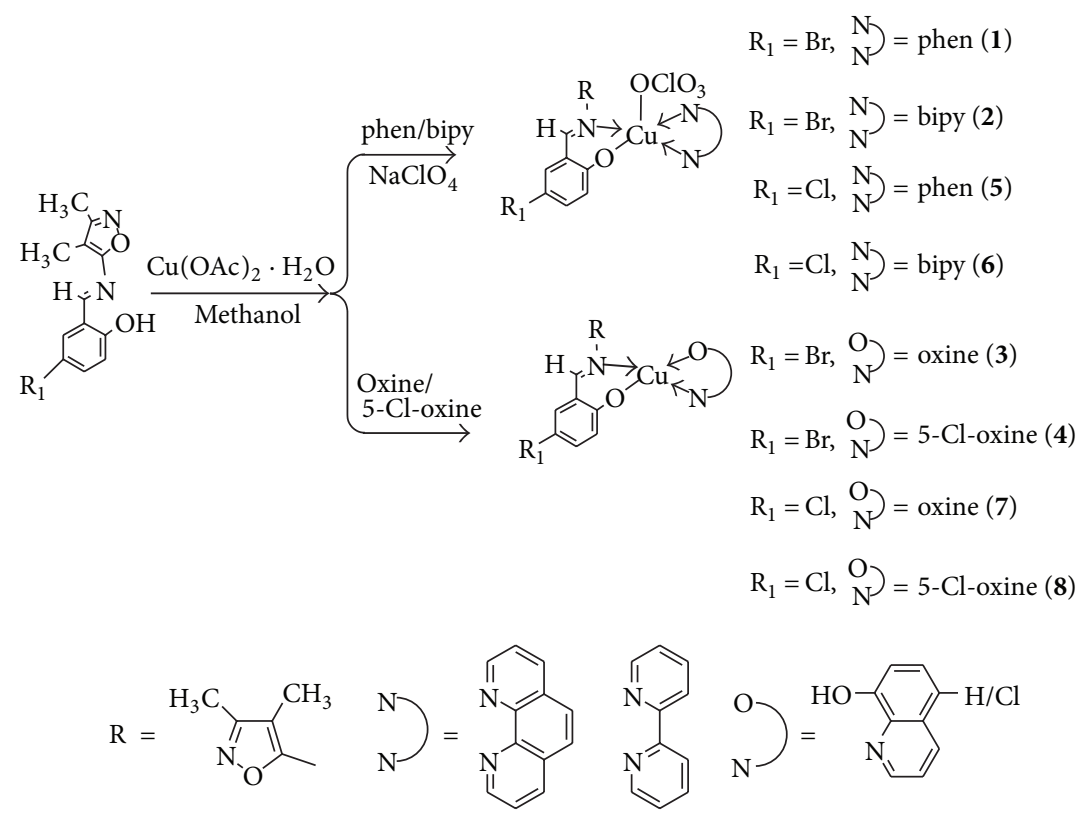

SCHEME 1: Schematic routes of the synthesis of the complexes.

TABLE 1: Analytical data of Schiff bases and their metal complexes.

\begin{tabular}{|c|c|c|c|c|c|c|c|}
\hline Compound & Formula & M.Wt. & $\mathrm{C}$ & $\mathrm{H}$ & $\mathrm{N}$ & $\mathrm{O}$ & $\mathrm{M}$ \\
\hline DMIIMBP & $\mathrm{C}_{12} \mathrm{H}_{11} \mathrm{BrN}_{2} \mathrm{O}_{2}$ & 296 & $48.76(48.84)$ & $3.58(3.76)$ & $9.34(9.49)$ & $10.54(10.84)$ & - \\
\hline$\left[\mathrm{Cu}(\mathrm{DMIIMBP})(\right.$ phen $\left.) \mathrm{ClO}_{4}\right]$ & $\mathrm{C}_{24} \mathrm{H}_{20} \mathrm{BrClCuN}_{4} \mathrm{O}_{6}$ & 637 & 44.69 (45.09) & $3.11(3.15)$ & $8.46(8.76)$ & $14.81(15.01)$ & $9.89(9.94)$ \\
\hline$\left[\mathrm{Cu}(\mathrm{DMIIMBP})(\right.$ bipy $\left.) \mathrm{ClO}_{4}\right]$ & $\mathrm{C}_{22} \mathrm{H}_{20} \mathrm{BrClCuN}_{4} \mathrm{O}_{6}$ & 613 & $42.33(42.94)$ & $3.17(3.28)$ & $8.94(9.11)$ & $15.14(15.60)$ & $10.18(10.33)$ \\
\hline [Cu(DMIIMBP)(oxine)] & $\mathrm{C}_{21} \mathrm{H}_{18} \mathrm{BrCuN}_{3} \mathrm{O}_{3}$ & 502 & $49.25(50.06)$ & $3.34(3.60)$ & $8.27(8.34)$ & $9.24(9.53)$ & $12.53(12.61)$ \\
\hline [Cu(DMIIMBP)(5-Cl-oxine)] & $\mathrm{C}_{21} \mathrm{H}_{17} \mathrm{BrClCuN}_{3} \mathrm{O}_{3}$ & 536 & $46.01(46.86)$ & $3.09(3.18)$ & $7.92(7.81)$ & $8.65(8.92)$ & $11.02(11.81)$ \\
\hline DMIIMCP & $\mathrm{C}_{12} \mathrm{H}_{11} \mathrm{ClN}_{2} \mathrm{O}_{2}$ & 250 & $57.05(57.49)$ & $4.34(4.42)$ & $11.07(11.17)$ & $12.24(12.76)$ & - \\
\hline$\left[\mathrm{Cu}(\mathrm{DMIIMCP})(\right.$ phen $\left.) \mathrm{ClO}_{4}\right]$ & $\mathrm{C}_{24} \mathrm{H}_{20} \mathrm{Cl}_{2} \mathrm{CuN}_{4} \mathrm{O}_{6}$ & 593 & $55.10(55.46)$ & $3.21(3.39)$ & $8.99(9.42)$ & $15.26(16.14)$ & $10.13(10.68)$ \\
\hline$\left[\mathrm{Cu}(\mathrm{DMIIMCP})\left(\right.\right.$ bipy)ClO $\left.{ }_{4}\right]$ & $\mathrm{C}_{22} \mathrm{H}_{20} \mathrm{Cl}_{2} \mathrm{CuN}_{4} \mathrm{O}_{6}$ & 569 & $41.98(46.29)$ & $3.05(3.53)$ & $9.14(9.81)$ & $15.95(16.82)$ & $10.82(11.13)$ \\
\hline [Cu(DMIIMCP)(oxine)] & $\mathrm{C}_{21} \mathrm{H}_{18} \mathrm{ClCuN}_{3} \mathrm{O}_{3}$ & 458 & $54.89(54.90)$ & $3.85(3.95)$ & $9.10(9.15)$ & $10.26(10.45)$ & $12.99(13.83)$ \\
\hline [Cu(DMIIMCP)(5-Cl-oxine)] & $\mathrm{C}_{21} \mathrm{H}_{17} \mathrm{Cl}_{2} \mathrm{CuN}_{3} \mathrm{O}_{3}$ & 492 & $50.99(51.08)$ & $3.19(3.47)$ & $8.14(8.51)$ & $9.11(9.72)$ & $12.67(12.87)$ \\
\hline
\end{tabular}

\section{Results and Discussion}

3.1. Characterization of Ligands. The two ligands DMIIMBP and DMIIMCP reported earlier were yellow in colour and stable to air and moisture. The physical and spectral data, such as IR, mass, ${ }^{1} \mathrm{H}-\mathrm{NMR}$, and ${ }^{13} \mathrm{C}-\mathrm{NMR}$, obtained for these ligands were in good agreement with the literature data [22].

3.2. Characterization of Metal Complexes. All the complexes were stable at room temperature and nonhygroscopic. On heating, they were decomposed at high temperatures. The complexes were insoluble in water but were soluble in DMSO. The composition of the complexes was deduced from the elemental analysis. From the data it was clear that the experimental values shown for each of the complexes were in good agreement with the theoretical values calculated for $1: 1: 1$ ratio (see Section 2.3 of materials and methods). Analytical data of Schiff bases and their metal complexes were presented in Table 1.
3.3. IR Spectra. The important infrared spectral bands and their assignments for the synthesized ligands and complexes were recorded as $\mathrm{KBr}$ pellets and were presented in Table 2. The IR data of the free ligands and its metal complexes were carried out within the IR range $4000-400 \mathrm{~cm}^{-1}$. In all the Schiff bases, azomethine stretching vibrations appear in the $1633-1605 \mathrm{~cm}^{-1}$ range. These bands were shifted to lower frequency region to the extent of $10-35 \mathrm{~cm}^{-1}$ in complexes, indicating the nitrogen of azomethine is coordinated with the metal ion [23-26]. A broad band around 3453 to $3446 \mathrm{~cm}^{-1}$ in ligands due to the phenolic $\mathrm{OH}$ group has disappeared in their complexes indicating coordination through phenolic hydroxyl group [27]. A medium intensity band around 1189 to $1159 \mathrm{~cm}^{-1}$ due to phenolic $\nu \mathrm{C}-\mathrm{O}$ group of the ligands shifted to higher or lower frequency region in their complexes, suggesting the participation of the oxygen of the hydroxyl group in bonding with the metal ion $[28,29]$. These facts suggest that these shifts are due to coordination of ligand with the metal atom by the azomethine nitrogen and phenolic oxygen. 
TABLE 2: Some important IR absorption frequencies $\left(\mathrm{cm}^{-1}\right)$ of Schiff bases and metal complexes.

\begin{tabular}{|c|c|c|c|c|c|c|}
\hline Compound & $v(\mathrm{OH})$ & $v(\mathrm{HC}=\mathrm{N})$ & $v(\mathrm{C}-\mathrm{O})$ & $v(\mathrm{M}-\mathrm{O})$ & $v(\mathrm{M}-\mathrm{N})$ & Other bands \\
\hline DMIIMBP & 3446 & 1641 & 1182 & - & - & $v(\mathrm{C}-\mathrm{Br}) 779$ \\
\hline$\left[\mathrm{Cu}(\mathrm{DMIIMBP})(\right.$ phen $\left.) \mathrm{ClO}_{4}\right]$ & - & 1620 & 1164 & 550 & 448 & $v(\mathrm{Cl}-\mathrm{O}) 1070,1104,1148$ \\
\hline$\left[\mathrm{Cu}(\mathrm{DMIIMBP})(\right.$ bipy$\left.) \mathrm{ClO}_{4}\right]$ & - & 1614 & 1162 & 548 & 445 & $v(\mathrm{Cl}-\mathrm{O}) 1034,1058,1110$ \\
\hline [Cu(DMIIMBP)(oxine)] & - & 1607 & 1167 and 1113 & 550 & 410 & - \\
\hline [Cu(DMIIMBP)(5-Cl-oxine)] & - & 1618 & 1159 and 1133 & 543 & 454 & $v(\mathrm{C}-\mathrm{Cl}) 780$ \\
\hline DMIIMCP & 3453 & 1605 & 1183 & - & - & $v(\mathrm{C}-\mathrm{Cl}) 778$ \\
\hline$\left[\mathrm{Cu}(\mathrm{DMIIMCP})(\right.$ phen $\left.) \mathrm{ClO}_{4}\right]$ & - & 1622 & 1164 & 552 & 434 & $v(\mathrm{Cl}-\mathrm{O}) 1071,1104,1148$ \\
\hline [Cu(DMIIMCP)(bipy) $\left.\mathrm{ClO}_{4}\right]$ & - & 1618 & 1162 & 550 & 419 & $v(\mathrm{Cl}-\mathrm{O}) 1036,1059,1112$ \\
\hline [Cu(DMIIMCP)(oxine)] & - & 1609 & 1189 and 1109 & 521 & 414 & - \\
\hline [Cu(DMIIMCP)(5-Cl-oxine)] & - & 1633 & 1183 and 1128 & 549 & 421 & $v(\mathrm{C}-\mathrm{Cl}) 776$ \\
\hline
\end{tabular}

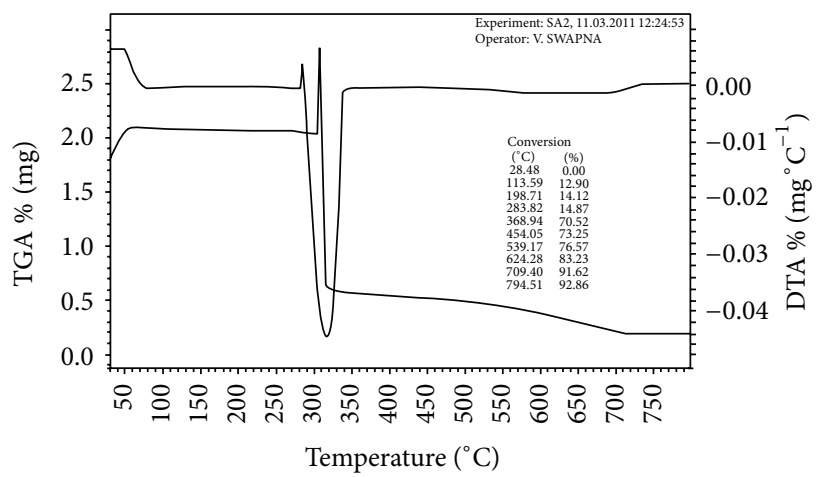

(a)

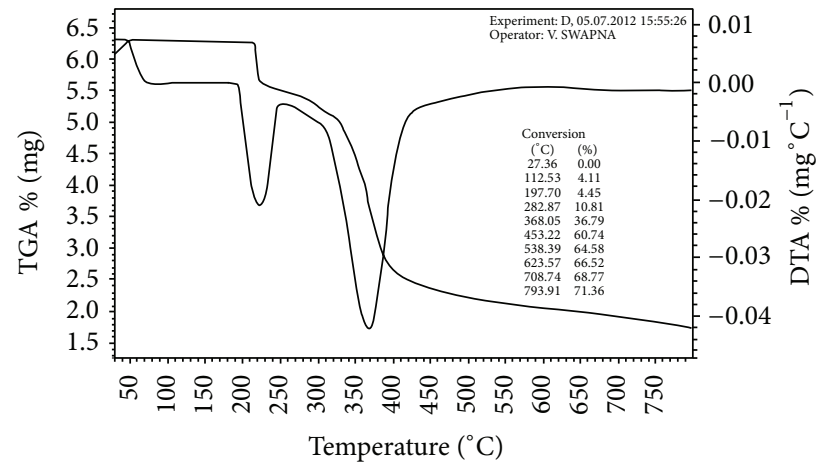

(b)

Figure 1: (a) The TGA spectrum of $\left[\mathrm{Cu}(\mathrm{DMIIMBP})(\mathrm{phen}) \mathrm{ClO}_{4}\right]$. (b) The TGA spectrum of $[\mathrm{Cu}(\mathrm{DMIIMCP})(\mathrm{oxine})]$.

This fact is also supported by the appearance of nonligand bands at appropriate positions in the far infrared region $\left(528-563 \mathrm{~cm}^{-1}\right.$ and $\left.410-454 \mathrm{~cm}^{-1}\right)$ due to $\nu \mathrm{M}-\mathrm{O}$ and $\nu \mathrm{M}-\mathrm{N}$ vibrations, respectively [30-33]. The peaks corresponding to the ring stretching frequencies $(\nu(\mathrm{C}=\mathrm{C})$ and $\nu(\mathrm{C}=\mathrm{N}))$ at 1505 , $1421 \mathrm{~cm}^{-1}$ of free phen and at $1509,1423 \mathrm{~cm}^{-1}$ of free bipy were shifted to higher frequencies upon complexation (1518, $1430 \mathrm{~cm}^{-1}$ for $1,1514,1446 \mathrm{~cm}^{-1}$ for $2,1516,1431 \mathrm{~cm}^{-1}$ for 5 , and $1516,1447 \mathrm{~cm}^{-1}$ for 6 ), indicating the coordination of the heterocyclic nitrogen atoms of phen and bipy with the metal ion. The characteristic out-of-plane hydrogen bending modes of free phen observed at 851 and $735 \mathrm{~cm}^{-1}$ and for bipy at 848 , $740 \mathrm{~cm}^{-1}$ were shifted to $849,722 \mathrm{~cm}^{-1}$ for $1,841,731 \mathrm{~cm}^{-1}$ for $2,849,720 \mathrm{~cm}^{-1}$ for 5 , and $830,30 \mathrm{~cm}^{-1}$ for 6 upon metal complexation [34]. The peaks around 1112, 1104, and $1034 \mathrm{~cm}^{-1}\left(\nu\left(\mathrm{ClO}_{4}\right)\right)$ confirm the presence of a coordinated perchlorate ion $[35,36]$. A strong $v(\mathrm{C}-\mathrm{O})$ band observed in the range between 1105 and $1135 \mathrm{~cm}^{-1}$ indicates the presence of oxine moiety in the complexes coordinated through its nitrogen and oxygen atoms as mononegative bidentate ligand [37-40].

3.4. Thermal Analysis. The thermograms of [Cu(DMIIMBP) (phen) $\left.\mathrm{ClO}_{4}\right]$ and $[\mathrm{Cu}(\mathrm{DMIIMCP})$ (oxine)] were given in Figures 1(a) and 1(b). From the Figures 1(a) and 1(b) it was found that the heating rates were suitably controlled at $10^{\circ} \mathrm{C}$ $\min ^{-1}$ under nitrogen atmosphere, and the weight loss was measured from the ambient temperature up to $1000^{\circ} \mathrm{C}$. The $\left[\mathrm{Cu}(\mathrm{DMIIMBP})(\right.$ phen $\left.) \mathrm{ClO}_{4}\right]$ complex undergoes 1 step of decomposition with the temperature range from $100^{\circ} \mathrm{C}$ to $370^{\circ} \mathrm{C}$ with an estimated mass loss of $70.52 \%$ (70.91\% calculated). In the thermogram it is observed that an exothermic peak appeared at $310^{\circ} \mathrm{C}$ due to perchlorate. This mass loss corresponds to the pyrolysis of the DMIIMBP and 1,10phenanthroline ligand molecules leaving $\mathrm{CuO}$ as a residue. The [Cu(DMIIMCP)(oxine)] complex undergoes 2 steps of decomposition with the temperature range from $100^{\circ} \mathrm{C}$ to $370^{\circ} \mathrm{C}$ with an estimated mass loss of $44.85 \%(45.01 \%$ calculated). This mass loss corresponds to the pyrolysis of the DMIIMCP and oxine ligand molecules leaving $\mathrm{CuO}$ as a residue.

3.5. Magnetic Susceptibility and Electronic Spectra. The electronic spectral data, molar extension coefficient values, and magnetic susceptibility values of the metal complexes are presented in Table 3 and from the data it is observed that the magnetic moment values of all $\mathrm{Cu}$ (II) complexes were in the range of 1.85-1.96 B.M. which is in accordance with one unpaired electron. In the present studies, all $\mathrm{Cu}$ (II) complexes show a single broad band in the range from 14,989 
TABLE 3: Electronic spectral data and magnetic susceptibility values of the $\mathrm{Cu}(\mathrm{II})$ complexes.

\begin{tabular}{|c|c|c|c|}
\hline Complex & Wave number $(v) \mathrm{cm}^{-1}(\mathrm{~nm})$ & $\varepsilon=10^{2} \mathrm{M}^{-1} \mathrm{~cm}^{-1}$ & $\mu_{\mathrm{eff}}(\mathrm{BM})$ \\
\hline$\left[\mathrm{Cu}(\mathrm{DMIIMBP})(\right.$ phen $\left.) \mathrm{ClO}_{4}\right]$ & $15,545(646)$ & 0.044 & 1.85 \\
\hline$\left[\mathrm{Cu}(\mathrm{DMIIMBP})(\right.$ bipy $\left.) \mathrm{ClO}_{4}\right]$ & $16,323(615)$ & 0.059 & 1.95 \\
\hline [Cu(DMIIMBP)(oxine)] & $16,891(592)$ & 0.061 & 1.92 \\
\hline [Cu(DMIIMBP)(5-Cl-oxine)] & $15,954(627)$ & 0.072 & 1.89 \\
\hline$\left[\mathrm{Cu}(\mathrm{DMIIMCP})(\right.$ phen $\left.) \mathrm{ClO}_{4}\right]$ & $15,210(662)$ & 0.056 & 1.93 \\
\hline$\left[\mathrm{Cu}(\mathrm{DMIIMCP})(\right.$ bipy $\left.) \mathrm{ClO}_{4}\right]$ & $14,989(665)$ & 0.063 & 1.89 \\
\hline [Cu(DMIIMCP)(oxine)] & $16,273(614)$ & 0.049 & 1.96 \\
\hline [Cu(DMIIMCP)(5-Cl-oxine)] & $16,920(591)$ & 0.045 & 1.87 \\
\hline
\end{tabular}

TABLE 4: ESR data of copper metal complexes 1-8.

\begin{tabular}{|c|c|c|c|c|c|}
\hline Compound & Temperature & $g_{11}$ & $g_{\perp}$ & $\Delta g$ & $G$ \\
\hline$\left[\mathrm{Cu}(\mathrm{DMIIMBP})(\right.$ phen $\left.) \mathrm{ClO}_{4}\right]$ & $300 \mathrm{~K}$ & 2.1539 & 2.0402 & 0.1137 & 3.8279 \\
\hline$\left[\mathrm{Cu}(\mathrm{DMIIMBP})(\right.$ bipy $\left.) \mathrm{ClO}_{4}\right]$ & $300 \mathrm{~K}$ & 2.1523 & 2.0536 & 0.0987 & 2.9238 \\
\hline [Cu(DMIIMBP)(oxine)] & $300 \mathrm{~K}$ & 2.1510 & 2.0391 & 0.1119 & 3.8624 \\
\hline [Cu(DMIIMBP)(5-Cl-oxine)] & $300 \mathrm{~K}$ & 2.1497 & 2.0411 & 0.1086 & 3.6437 \\
\hline$\left[\mathrm{Cu}(\mathrm{DMIIMCP})(\right.$ phen $\left.) \mathrm{ClO}_{4}\right]$ & $300 \mathrm{~K}$ & 2.1594 & 2.0431 & 0.1162 & 3.6928 \\
\hline$\left[\mathrm{Cu}(\mathrm{DMIIMCP})(\right.$ bipy $\left.) \mathrm{ClO}_{4}\right]$ & $300 \mathrm{~K}$ & 2.1710 & 2.0616 & 0.1093 & 2.841 \\
\hline [Cu(DMIIMCP)(oxine)] & $300 \mathrm{~K}$ & 2.1498 & 2.0423 & 0.1075 & 3.5416 \\
\hline [Cu(DMIIMCP)(5-Cl-oxine)] & $300 \mathrm{~K}$ & 2.1526 & 2.0426 & 0.1099 & 3.5807 \\
\hline
\end{tabular}

to $16,920 \mathrm{~cm}^{-1}$ due to transition between ${ }^{2} \mathrm{~B}_{1 \mathrm{~g}} \rightarrow{ }^{2} \mathrm{E}_{g}$ suggesting square pyramidal geometry and square planner geometry. Square pyramidal and square planar $\mathrm{Cu}(\mathrm{II}) \mathrm{com}-$ plexes were expected to give three bands. However, these three bands usually overlap in these complexes to give only one broad absorption band. The electronic spectral and magnetic moment data of all $\mathrm{Cu}$ (II) complexes suggest the square pyramidal geometry for complexes 1, 2, 5, and 6 and square planar geometry for $\mathbf{3}, \mathbf{4}, 7$, and $8 \mathrm{Cu}(\mathrm{II})$ complexes.

3.6. ESR Spectra. ESR spectra of all Cu(II) complexes were recorded as polycrystalline sample on $\mathrm{X}$ band at frequency $9.3 \mathrm{GHz}$ under the magnetic field strength $3400 \mathrm{G}$. The ESR data of copper metal complexes 1-8 are presented in Table 4. A representative ESR spectrum of $\left[\mathrm{Cu}(\mathrm{DMIIMBP})(\right.$ phen $\left.) \mathrm{ClO}_{4}\right]$ is shown in Figure 2. According to the data $g_{\|}$and $g_{\perp}$ values for all $\mathrm{Cu}$ (II) complexes are found to be in the range of 2.149-2.171 and 2.039-2.061, respectively. From the data, it is clear that $g_{\|}>g_{\perp}>2.0023\left(g_{e}\right)$ which suggest the unpaired electron present in $\mathrm{d}_{x 2-y 2}$ orbital giving ${ }^{2} \mathrm{~B}_{1 g}$ as the ground state and all the complexes are in square planar geometry [41]. Further it was observed that the $g_{\|}$values for all $\mathrm{Cu}(\mathrm{II})$ complexes were less than 2.3 in agreement with the covalent character of the metal ligand bond. The $g$ values are related to axial symmetry parameter $G$ by the Hathway expression, that is, $G=\left(g_{\|}-2.0023\right) /\left(g_{\perp}-2.0023\right)$.

According to the data, the $G$ values for all $\mathrm{Cu}(\mathrm{II})$ complexes were found to be less than 4 indicating the ligands were strong field and the metal ligand bonding in these complexes is covalent $[42,43]$.

\section{Molecular Modeling}

Successful docking was performed for the selected DMIIMBP and DMIIMCP compounds and their corresponding Gold Fitness score and Chem scores were given in Tables 5(a) and 5(b). The interactions of DMIIMBP and DMIIMCP with protein were shown in Figures 3(a) and 3(b).

For any docked pose [44], the Gold score is calculated generally as the sum of the electrostatic, van der Waals, and hydrophobic interactions and hydrogen bonding interactions. Chem score function includes metal-binding and solvation terms. The Gold Fitness ranges from 57.67 to 57.70 and Chem score ranges from 19.16 to 19.03 . Docking results revealed that DMIIMBP and DMIIMCP ligands are involved in hydrogen bonding and van der Waals interactions with the active site residues of DNA topoisomerase I. Among these ligands, DMIIMBP was the best inhibitor of DNA topoisomerase I. The binding energy and the total energy of DMIIMBP and DMIIMCP were listed in Table 6. The LUMO and HOMO structures of DMIIMBP and DMIIMCP were shown in Figures 4(a) and 4(b). The energy levels of LUMO and HOMO reveal that the DMIIMBP was very potential in antimicrobial activity.

\section{Antimicrobial Activity}

In the present investigation, biological activity of the ligands, namely, DMIIMBP, DMIIMCP and their ternary complexes with $\mathrm{Cu}(\mathrm{II})$, has been screened for antimicrobial activity against bacteria (E. coli and $P$. aeruginosa) and fungi ( $A$. niger and $R$. oryzae) by paper disc method. The concentration 


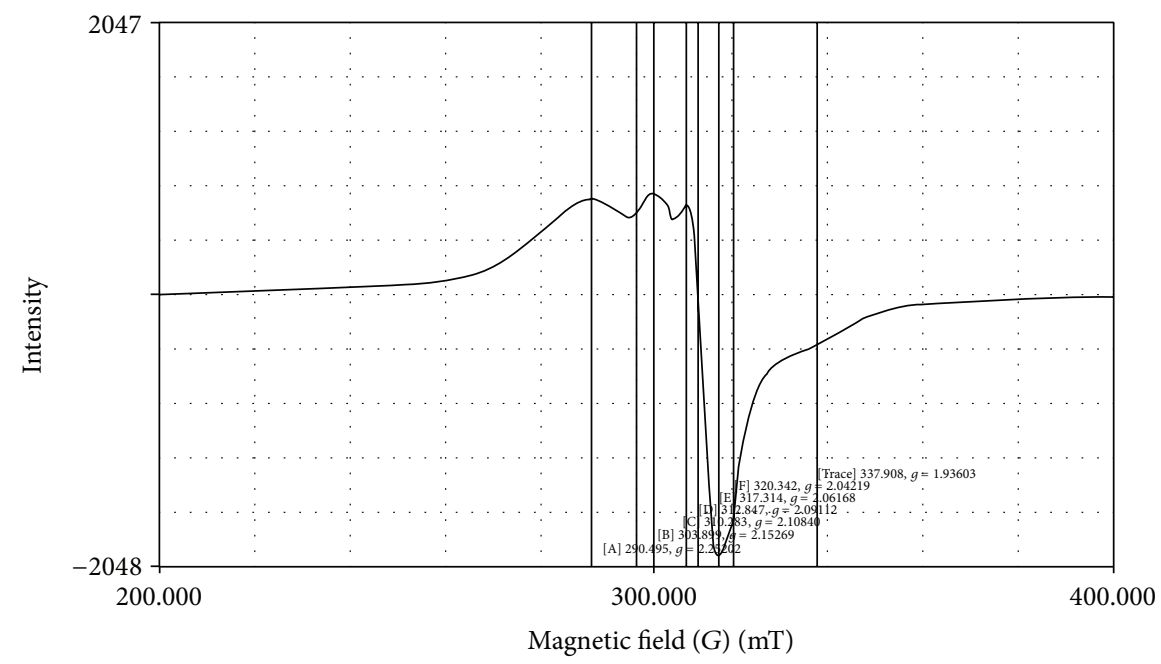

FIgURE 2: The ESR spectrum of $\left[\mathrm{Cu}(\mathrm{DMIIMBP})(\mathrm{phen}) \mathrm{ClO}_{4}\right]$.

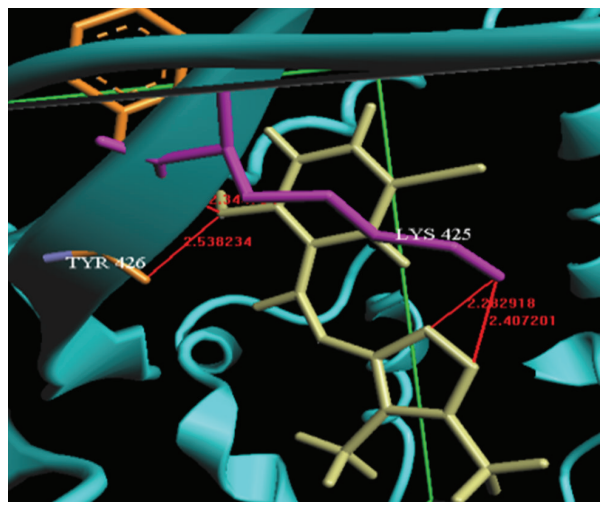

(a)

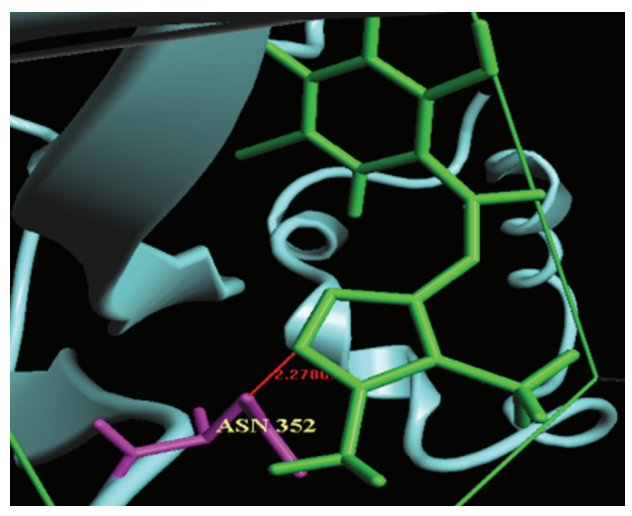

(b)

FIGURE 3: (a) Interactions between TYR and LYS-DMIIMBP crystal ligand (yellow) and target protein (pale green). The TYR residue (gray) and LYS residue (pink) interactions are shown in CPK model. Hydrogen bonding interactions were represented as line (red). (b) Interactions between ASN-DMIIMCP crystal ligand (green) and target protein (pale green). The ASN residue (pink) interactions are shown in CPK model. Hydrogen bonding interactions were represented as line (red).

TABLE 5: (a) Gold Fitness values of the ligands DMIIMBP and DMIIMCP. (b) Chem score values of the ligands DMIIMBP and DMIIMCP.

(a)

\begin{tabular}{lcccccc}
\hline S. number & Compound & Gold Fitness & S(hb_ext) & S(vdw_ext) & S(hb_int) & S(vdw_int) \\
\hline 1 & DMIIMBP & 57.67 & 4.67 & 41.97 & 0.00 & -4.71 \\
2 & DMIIMCP & 57.70 & 4.55 & 41.52 & 0.00 & -3.94 \\
\hline
\end{tabular}

(b)

\begin{tabular}{lcccccccc}
\hline S. number & Compound & Chem score & DG & S(hbond) & S(metal) & S(lipo) & DE(clash) & DE(int) \\
\hline 1 & DMIIMBP & 19.16 & -19.44 & 1.88 & 0.00 & 87.41 & 0.03 & 0.25 \\
2 & DMIIMCP & 19.03 & -19.23 & 1.90 & 0.00 & 85.10 & 0.01 & 0.18 \\
\hline
\end{tabular}



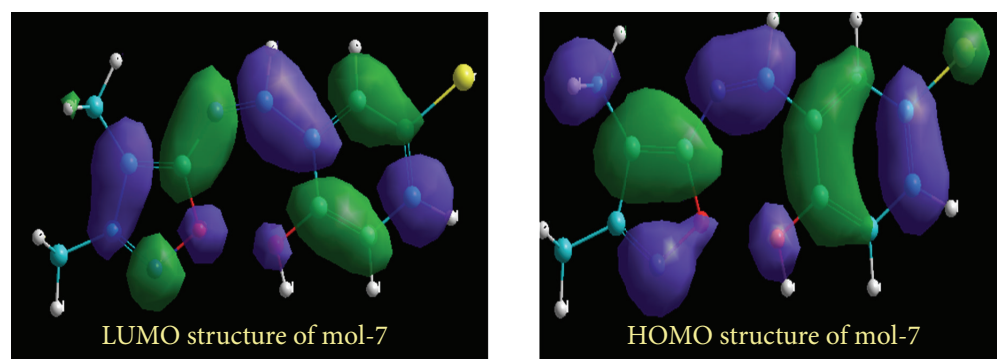

(a)
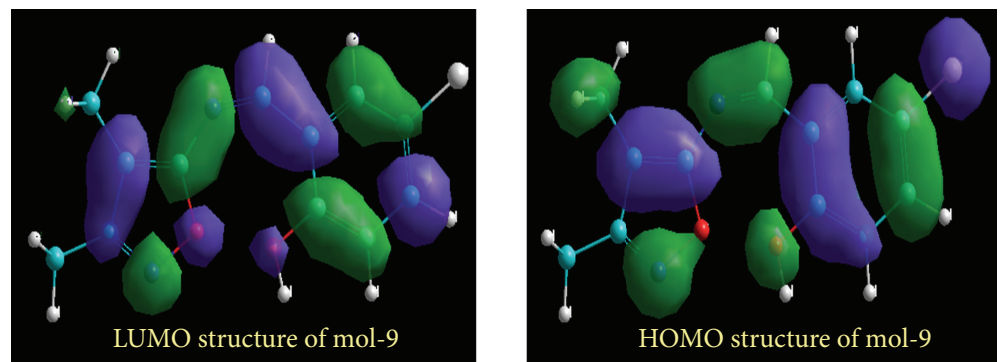

(b)

FIgURE 4: (a) LUMO and HOMO structures for DMIIMBP. (b) LUMO and HOMO structures for DMIIMCP.

TABLE 6: The energy values of the ligands DMIIMBP and DMIIMCP.

\begin{tabular}{lcccc}
\hline Molecule & $\begin{array}{c}\text { HOMO } \\
(\mathrm{eV})\end{array}$ & $\begin{array}{c}\text { LUMO } \\
(\mathrm{eV})\end{array}$ & $\begin{array}{c}\text { Binding energy } \\
(\mathrm{kcal} / \mathrm{mol})\end{array}$ & $\begin{array}{c}\text { Total energy } \\
(\mathrm{kcal} / \mathrm{mol})\end{array}$ \\
\hline DMIIMBP & -8.96 & -1.09 & -7.36 & -2959.70 \\
DMIIMCP & -8.89 & -1.06 & -7.49 & -2976.18 \\
\hline
\end{tabular}

for these samples was maintained as $1 \mathrm{mg} / \mathrm{mL}$ in DMSO. The results thus obtained were explained on the basis of Overtone's concept and Chelation theory $[45,46]$. The mode of action of the compounds may involve formation of a hydrogen bond through the azomethine group with the active centers of cell constituents, resulting in an interference with the normal cell process [47].

The variation in the activity of different complexes against different organisms depends either on the impermeability of the cells of the microbes or difference in ribosome of microbial cells. A comparison of the biological activity of the synthesized compounds with some known antibiotics (ciprofloxacin and ketoconazole) is presented in Table 7. It is observed that some of Schiff base metal complexes exhibit better activity than the corresponding ligands.

\section{Cytotoxic Activity}

The cytotoxic activity of $\mathrm{Cu}(\mathrm{II})$ complexes was assayed on cultured human cervical carcinoma cell lines (HeLa) for $72 \mathrm{~h}$ to the medium containing the respective complexes at 2 to $10 \mu \mathrm{g} / \mathrm{mL}$ concentration and adopting MTT assay and results were given in Table 8 .

The cytotoxic activity determined according to the dose values of the exposure of the complex required to

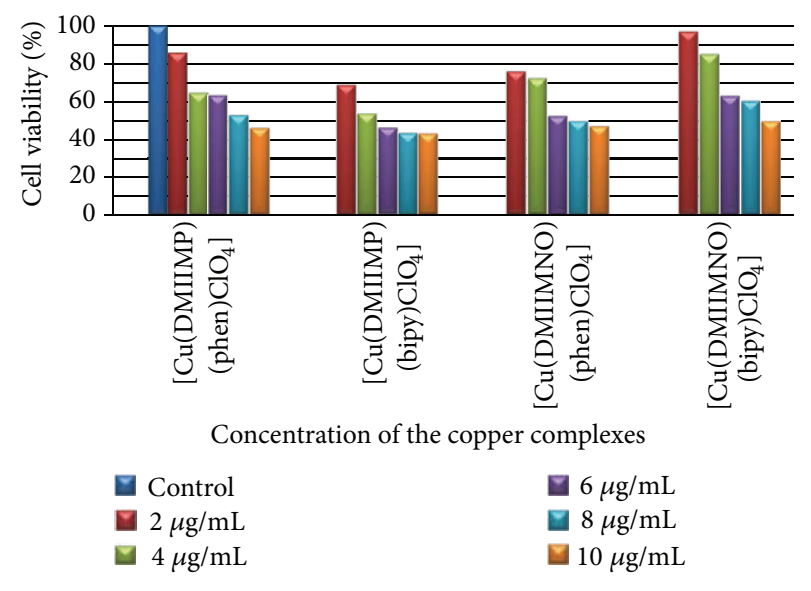

FIGURE 5: Percentage of cell viability versus different concentrations for HeLa cells exposed to the metal complexes after $72 \mathrm{~h}$ incubation.

reduce survival of the cell was given in Figure 5. The toxicities of $10 \mu \mathrm{g} / \mathrm{mL}$ of [ $\mathrm{Cu}(\mathrm{DMIIMBP})($ phen $\left.) \mathrm{ClO}_{4}\right](\mathbf{1})$, $\left[\mathrm{Cu}(\mathrm{DMIIMBP})\right.$ (bipy) $\left.\mathrm{ClO}_{4}\right](2), \quad[\mathrm{Cu}(\mathrm{DMIIMCP})$ (phen) $\left.\mathrm{ClO}_{4}\right](5)$, and $\left[\mathrm{Cu}(\mathrm{DMIIMCP})\left(\right.\right.$ bipy) $\left.\mathrm{ClO}_{4}\right](6)$ complexes were found to be $54.41 \%, 57.51 \%, 52.79 \%$, and $50.22 \%$, respectively. According to these results, [Cu(DMIIMBP) (bipy) $\left.\mathrm{ClO}_{4}\right](2)$ complex was found to behave as a good antitumor agent on HeLa cell lines. The $\mathrm{IC}_{50}$ values obtained in this study were given in Table 9 . The $\mathrm{IC}_{50}$ value of the $[\mathrm{Cu}$ (DMIIMBP) (phen) $\left.\mathrm{ClO}_{4}\right](\mathbf{1}), \quad\left[\mathrm{Cu}(\mathrm{DMIIMBP})(\right.$ bipy $\left.) \mathrm{ClO}_{4}\right]$ (2), $\left[\mathrm{Cu}(\mathrm{DMIIMCP})(\right.$ phen $\left.) \mathrm{ClO}_{4}\right](5)$, and $[\mathrm{Cu}(\mathrm{DMIIMCP})$ (bipy) $\left.\mathrm{ClO}_{4}\right](6)$ complexes was higher for the $72 \mathrm{~h}$ treatment groups, that is, $10 \pm 0.09 \mu \mathrm{g} / \mathrm{mL}$, whereas for [Cu(DMIIMBP) (bipy) $\left.\mathrm{ClO}_{4}\right]$ the $\mathrm{IC}_{50}$ value is $5 \pm 0.06 \mu \mathrm{g} / \mathrm{mL}$. 
TABLE 7: Antimicrobial activity of the Schiff bases and metal complexes.

\begin{tabular}{|c|c|c|c|c|}
\hline Complex & E. Coli & P. aeruginosa & R. oryzae & A. niger \\
\hline DMIIMBP & 17 & 14 & 11 & 8 \\
\hline$\left[\mathrm{Cu}(\mathrm{DMIIMBP})(\right.$ phen $\left.) \mathrm{ClO}_{4}\right]$ & 19 & 16 & 13 & 10 \\
\hline$\left[\mathrm{Cu}(\mathrm{DMIIMBP})\right.$ (bipy) $\left.\mathrm{ClO}_{4}\right]$ & 18 & 15 & 12 & 9 \\
\hline [Cu(DMIIMBP)(oxine)] & 16 & 14 & 10 & 8 \\
\hline [Cu(DMIIMBP)(5-Cl-oxine)] & 18 & 17 & 9 & 9 \\
\hline DMIIMCP & 16 & 13 & 10 & 10 \\
\hline$\left[\mathrm{Cu}(\mathrm{DMIIMCP})(\right.$ phen $\left.) \mathrm{ClO}_{4}\right]$ & 17 & 16 & 11 & 12 \\
\hline$\left[\mathrm{Cu}(\mathrm{DMIIMCP})(\right.$ bipy $\left.) \mathrm{ClO}_{4}\right]$ & 18 & 15 & 11 & 11 \\
\hline [Cu(DMIIMCP)(oxine)] & 15 & 14 & 8 & 8 \\
\hline [Cu(DMIIMCP)(5-Cl-oxine)] & 16 & 15 & 9 & 10 \\
\hline Ciprofloxacin & 20 & 18 & - & - \\
\hline Ketoconazole & - & - & 15 & 13 \\
\hline
\end{tabular}

TABLE 8: In vitro cytotoxicity (HeLa cell line) of $\mathrm{Cu}$ (II) complexes.

\begin{tabular}{|c|c|c|c|c|c|c|c|}
\hline $\begin{array}{l}\text { Concentration } \\
(\mu \mathrm{g} / \mathrm{mL})\end{array}$ & Absorbance & Cell viability (\%) & Toxicities (\%) & $\begin{array}{l}\text { Concentration } \\
(\mu \mathrm{g} / \mathrm{mL})\end{array}$ & Absorbance & Cell viability (\%) & Toxicities (\%) \\
\hline Control & 0.1165 & 100 & 0 & Control & 0.1165 & 100 & 0 \\
\hline $\begin{array}{l}{[\mathrm{Cu}(\mathrm{DMIIMBP})} \\
\left.(\text { phen }) \mathrm{ClO}_{4}\right]\end{array}$ & & & & $\begin{array}{l}{[\mathrm{Cu}(\mathrm{DMIIMBP})} \\
\left.(\text { bipy }) \mathrm{ClO}_{4}\right]\end{array}$ & & & \\
\hline 2 & 0.1011 & 86.90 & 13.10 & 2 & 0.0800 & 68.66 & 31.34 \\
\hline 4 & 0.0751 & 64.35 & 35.65 & 4 & 0.0625 & 53.64 & 46.36 \\
\hline 6 & 0.0732 & 63.05 & 36.95 & 6 & 0.0534 & 45.83 & 54.17 \\
\hline 8 & 0.0611 & 52.50 & 47.50 & 8 & 0.0502 & 43.09 & 56.91 \\
\hline 10 & 0.0532 & 45.59 & 54.41 & 10 & 0.0495 & 42.49 & 57.51 \\
\hline $\begin{array}{l}{[\mathrm{Cu}(\mathrm{DMIIMCP})} \\
\left.(\text { phen }) \mathrm{ClO}_{4}\right]\end{array}$ & & & & $\begin{array}{l}{[\mathrm{Cu}(\mathrm{DMIIMCP})} \\
\left.(\text { bipy }) \mathrm{ClO}_{4}\right]\end{array}$ & & & \\
\hline 2 & 0.0880 & 75.53 & 24.47 & 2 & 0.1120 & 96.13 & 3.87 \\
\hline 4 & 0.0833 & 71.50 & 28.50 & 4 & 0.0985 & 84.54 & 15.46 \\
\hline 6 & 0.0605 & 51.93 & 48.07 & 6 & 0.0726 & 62.31 & 37.69 \\
\hline 8 & 0.0580 & 49.78 & 50.22 & 8 & 0.0696 & 59.74 & 40.26 \\
\hline 10 & 0.0550 & 47.21 & 52.79 & 10 & 0.0580 & 49.78 & 50.22 \\
\hline
\end{tabular}

TABLE 9: $\mathrm{IC}_{50}$ range of $\mathrm{Cu}$ (II) complexes for HeLa cells.

\begin{tabular}{lc}
\hline Complex & $\mathrm{IC}_{50}(\mu \mathrm{g} / \mathrm{mL})$ \\
\hline$\left[\mathrm{Cu}(\mathrm{DMIIMBP})(\right.$ phen $\left.) \mathrm{ClO}_{4}\right]$ & $9 \pm 0.03$ \\
{$\left[\mathrm{Cu}(\right.$ DMIIMBP $)($ bipy $\left.) \mathrm{ClO}_{4}\right]$} & $5 \pm 0.06$ \\
{$\left[\mathrm{Cu}(\right.$ DMIIMCP $)($ phen $\left.) \mathrm{ClO}_{4}\right]$} & $8 \pm 0.03$ \\
{$\left[\mathrm{Cu}(\right.$ DMIIMCP $)($ bipy $\left.) \mathrm{ClO}_{4}\right]$} & $10 \pm 0.09$ \\
\hline
\end{tabular}

\section{DNA Cleavage Studies}

The cleavage activity was demonstrated by gel-electrophoresis experiments using supercoiled (SC) plasmid pBR 322 DNA in a medium TAE buffer. These experiments were monitored by the addition of varying concentrations of the complex $(40-200 \mu \mathrm{M})$. When DNA was incubated with increasing concentrations of the complexes, SC DNA was degraded to nicked circular (NC) form. The catalytic activities of complexes 1 and 2 were depicted in Figure 6.
The activity of $\mathbf{1}$ starts at a concentration as low as $40 \mu \mathrm{M}$. At $40 \mu \mathrm{M}, 80 \mu \mathrm{M}$, and $120 \mu \mathrm{M}$, a complete conversion of SC plasmid DNA into the NC form was observed, and the DNA completely smeared is shown in Figure 6(a) (lanes 2,3 , and 4 ). In contrast, only $63 \%$ cleavage was achieved with 2 as shown in Figure 6(a) (lanes 6, 7 and 8). This may be due to the efficient binding of 1 with DNA compared to that of 2 . To ensure that the $\mathrm{Cu}$ complexes were solely responsible for the cleavage, several control experiments were performed under identical conditions. No cleavage of DNA was observed with free $\mathrm{Cu}(100 \mathrm{~mm})$ and free ligands $(100 \mathrm{~mm})$. In a control experiment with DMSO $(1 \mathrm{~mm})$, a known radical scavenger, only slight inhibition (ca. 2\%) of DNA cleavage was observed, ruling out the possibility of DNA cleavage via $\mathrm{OH}$-based depurination pathway and also a possible oxidative cleavage $[48,49]$. When circular plasmid DNA is subjected to electrophoresis, relatively fast migration will be observed for the intact supercoil form (Form-I). If scission occurs on one strand (nicking), the supercoil will 


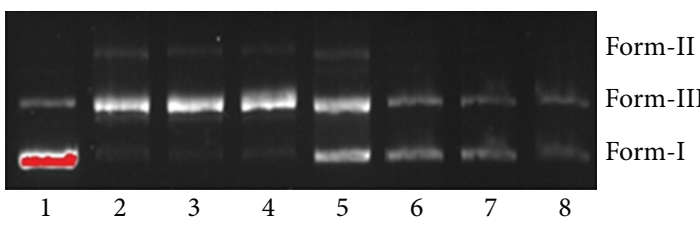

(a)

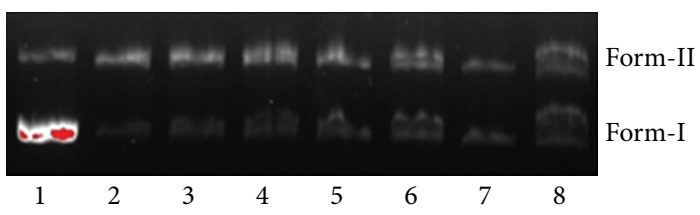

(b)

FIGURE 6: Agarose gel electrophoresis patterns for the oxidative cleavage of pBR 322 DNA by 1 and 2(a) and photolytic cleavage of pBR 322 DNA by 1 and 2(b). (a) Lane 1, DNA control; Lane 2, DNA+1 $(40 \mu \mathrm{M})+\mathrm{H}_{2} \mathrm{O}_{2}(1 \mathrm{mM})$; Lane 3, DNA+1 $(80 \mu \mathrm{M})+\mathrm{H}_{2} \mathrm{O}_{2}(1 \mathrm{mM}) ; \mathrm{Lane} 4$, DNA+1 $(120 \mu \mathrm{M})+\mathrm{H}_{2} \mathrm{O}_{2}(1 \mathrm{mM}) ;$ Lane 5, DNA + $\mathrm{H}_{2} \mathrm{O}_{2}(1 \mathrm{mM})+$ DMSO $(1 \mathrm{mM})$. Lane 6, DNA+2 $(40 \mu \mathrm{M})+\mathrm{H}_{2} \mathrm{O}_{2}(1 \mathrm{mM}) ; \mathrm{Lane}$, DNA+2 $(80 \mu \mathrm{M})+\mathrm{H}_{2} \mathrm{O}_{2}(1 \mathrm{mM}) ;$ Lane 8, DNA $+2(120 \mu \mathrm{M})+\mathrm{H}_{2} \mathrm{O}_{2}(1 \mathrm{mM}) ;$ (b) Lane 1, DNA control; Lane 2, DNA+1 $(40 \mu \mathrm{M})+\mathrm{H}_{2} \mathrm{O}_{2}(1 \mathrm{mM}) ; \mathrm{Lane}$ 3, DNA+1 $(80 \mu \mathrm{M})+\mathrm{H}_{2} \mathrm{O}_{2}(1 \mathrm{mM}) ;$ Lane 4, DNA+1 $(120 \mu \mathrm{M})+\mathrm{H}_{2} \mathrm{O}_{2}(1 \mathrm{mM}) ;$ Lane 5, DNA + DMSO (1 mM). Lane 6, DNA+2 (40 $\left.\mu \mathrm{M}\right)+$ $\mathrm{H}_{2} \mathrm{O}_{2}(1 \mathrm{mM})$; Lane 7, DNA+2 $(80 \mu \mathrm{M})+\mathrm{H}_{2} \mathrm{O}_{2}(1 \mathrm{mM})$; Lane 8, DNA+2 $(120 \mu \mathrm{M})+\mathrm{H}_{2} \mathrm{O}_{2}(1 \mathrm{mM})$.

relax to generate a slower-moving open circular form (FormII). If both strands were cleaved, a linear form (Form-III) that migrates between Form-I and Form-II will be generated [50]. The cleavage effect upon irradiation of the plasmid pBR322 DNA in the presence of different concentrations of complexes 1 and 2 has been tested and is shown in Figure 6(b): Lane 1 DNA alone, Lanes 2-4DNA + complex (1), and Lanes 6-8 DNA + complex (2) with increasing concentration $(40 \mu \mathrm{M}, 80 \mu \mathrm{M}$, and $120 \mu \mathrm{M})$ of complex. Form-II increases and Form-I decreases gradually as the concentration of complex increases. The results suggest concentration-dependent single-strand cleavage of supercoiled Form-I to the nicked Form-II. Under comparable experimental conditions, complex 1 exhibits more effective DNA cleavage activity than complex 2 . The different cleaving efficiency may be ascribed to the different binding affinity of complexes to DNA.

\section{Conclusions}

Mixed ligand metal chelates of $\mathrm{Cu}(\mathrm{II})$ with DMIIMBP/ DMIIMCP and phen/bipy/oxine/5-Cl-oxine have been synthesized and characterized. The metal ligand stoichiometry in all complexes was found to be $1: 1: 1$. The Schiff bases act as monobasic bidentate coordinating through nitrogen of azomethine and phenolic oxygen atom. Based on analytical, conductance, IR, magnetic moments, electronic, and ESR spectral data for the complexes 1, 2, 5, and 6 and for complexes $3,4,7$, and $\mathbf{8}$, five-coordinated square pyramidal geometry and four-coordinated square planar geometry are assigned, respectively. Docking studies of the Schiff bases reveal that DMIIMBP Schiff base was more potential for antimicrobial activity. Further it is observed that metal complexes showed higher activity than corresponding Schiff bases and some complexes showed comparable activity with standard drug. The cytotoxicity of all the $\mathrm{Cu}(\mathrm{II})$ complexes was assayed and it was found that the cytotoxicity of the $\left[\mathrm{Cu}(\mathrm{DMIIMBP})(\right.$ bipy $\left.) \mathrm{ClO}_{4}\right]$ complex at $10 \mu \mathrm{g} / \mathrm{mL}$ concentration shows $57.51 \%$ toxicity suggesting good antitumor agent on human cervical carcinoma cell lines. In the DNA cleavage studies it is observed that the $\left[\mathrm{Cu}(\mathrm{DMIIMBP})(\mathrm{phen}) \mathrm{ClO}_{4}\right](\mathbf{1})$ shows more potential activity than the other complexes due to its higher planarity nature.

\section{Conflict of Interests}

The authors declare that there is no conflict of interests regarding the publication of this paper.

\section{Acknowledgments}

The authors are grateful to the Head of Department of the Chemistry for providing the necessary facilities. The authors are thankful to the Director, CFRD, Osmania University, Hyderabad, and the Director, IICT, Hyderabad, for providing spectral and analytical data. The authors are also thankful to UGC, New Delhi, for providing financial assistance.

\section{References}

[1] J. Nordenberg, A. Novogrodsky, E. Beery, M. Patia, L. Wasserman, and A. Warshawsky, "Anti-proliferative effects and phenotypic alterations induced by 8-hydroxyquinoline in melanoma cell lines," European Journal of Cancer, vol. 26, no. 8, pp. 905907, 1990.

[2] A.-Y. Shen, S.-N. Wu, and C.-T. Chiu, "Synthesis and cytotoxicity evaluation of some 8-hydroxyquinoline derivatives," Journal of Pharmacy and Pharmacology, vol. 51, no. 5, pp. 543-548, 1999.

[3] S. Zhai, L. Yang, Q. C. Cui, Y. Sun, Q. P. Dou, and B. Yan, "Tumor cellular proteasome inhibition and growth suppression by 8 -hydroxyquinoline and clioquinol requires their capabilities to bind copper and transport copper into cells," Journal of Biological Inorganic Chemistry, vol. 15, no. 2, pp. 259-269, 2010.

[4] B. S. Tovrog, D. J. Kitko, and R. S. Drago, "Nature of the bound $\mathrm{O}_{2}$ in a series of cobalt dioxygen adducts," Journal of the American Chemical Society, vol. 98, no. 17, pp. 5144-5153, 1976.

[5] A. A. El-Sherif, M. R. Shehata, M. M. Shoukry, and M. H. Barakat, "Synthesis, characterization, equilibrium study and biological activity of $\mathrm{Cu}(\mathrm{II}), \mathrm{Ni}(\mathrm{II})$ and $\mathrm{Co}(\mathrm{II})$ complexes of polydentate Schiff base ligand," Spectrochimica Acta A, vol. 96, pp. 889-897, 2012.

[6] T. M. Aminabhavi, N. S. Biradar, S. B. Patil, V. L. Roddabasanagoudar, and W. E. Rudzinski, "Amino acid schiff base complexes of dimethyldichlorosilane," Inorganica Chimica Acta, vol. 107, no. 4, pp. 231-234, 1985.

[7] R. Hernandez-Molina and A. Mederos, "Acyclic and macrocyclic Schiff base ligands," in Comprehensive Coordination Chemistry, J. A. McCleverty and T. J. Meyer, Eds., vol. 1, Elsevier, London, UK, 2nd edition, 2005. 
[8] I. S. MacPherson and M. E. P. Murphy, "Type-2 coppercontaining enzymes," Cellular and Molecular Life Sciences, vol. 64, no. 22, pp. 2887-2899, 2007.

[9] D. J. Kosman, "Multicopper oxidases: a workshop on copper coordination chemistry, electron transfer, and metallophysiology," Journal of Biological Inorganic Chemistry, vol. 15, no. 1, pp. 15-28, 2010.

[10] K. Jomova and M. Valko, "Advances in metal-induced oxidative stress and human disease," Toxicology, vol. 283, no. 2-3, pp. 6587, 2011.

[11] M. Ř́ha, J. Karlíčková, T. Filipský, K. Macáková, R. Hrdina, and P. Mladěnka, "Novel method for rapid copper chelation assessment confirmed low affinity of D-penicillamine for copper in comparison with trientine and 8-hydroxyquinolines," Journal of Inorganic Biochemistry, vol. 123, pp. 80-87, 2013.

[12] P. Talukder, A. Datta, S. Mitra, and G. Rosair, "Square planar complexes of $\mathrm{Cu}(\mathrm{II})$ with an $\mathrm{N}_{2} \mathrm{O}$ donor set of a new Schiff base ligand: synthesis and structural aspects," Zeitschrift fur Naturforschung B: Journal of Chemical Sciences, vol. 59, no. 6, pp. 655-660, 2004.

[13] V. V. Bon, "The first square-planar copper(II) 1:2 complex with differently coordinated 2-hydroxybenzaldehyde 4allylthiosemicarbazone ligands," Acta Crystallographica C, vol. 66, no. 10, pp. m300-m302, 2010.

[14] C. P. Pradeep, P. S. Zacharias, and S. K. Das, "Synthesis and characterization of a chiral dimeric copper(II) complex: crystal structure of $\left[\mathrm{Cu}_{2}(\mu-\mathrm{Cl})_{2}(\mathrm{HL})_{2}\right]-\mathrm{H}_{2} \mathrm{O}\left(\mathrm{H}_{2} \mathrm{~L}=S\right.$ - $(-)-2-$ [(2-hydroxy-1-phenyl- ethylimino)-methyl]-phenol)," Journal of Chemical Sciences, vol. 117, no. 2, pp. 133-137, 2005.

[15] N. Raman, S. Ravichandran, and C. Thangaraja, "Copper(II), cobalt(II), nickel(II) and zinc(II) complexes of Schiff base derived from benzil-2,4-dinitrophenylhydrazone with aniline," Journal of Chemical Sciences, vol. 116, no. 4, pp. 215-219, 2004.

[16] P. G. Sammes and G. Yahioglu, "1,10-Phenanthroline: a versatile ligand," Chemical Society Reviews, vol. 23, no. 5, pp. 327-334, 1994.

[17] N. Farrel, Transition Metal Complexes as Drugs and Chemotherapeutic Agents, Kluwer Academic, Dordrecht, The Netherlands, 1989.

[18] D. J. Gravert and J. H. Grifffin, "Specific DNA cleavage mediated by manganese complex [SalenMn(III)]+," The Journal of Organic Chemistry, vol. 58, no. 4, pp. 820-822, 1993.

[19] S. Routier, J.-L. Bernier, M. J. Waring, P. Colson, C. Houssier, and C. Bailly, "Synthesis of a functionalized salen-copper complex and its interaction with DNA," The Journal of Organic Chemistry, vol. 61, no. 7, pp. 2326-2331, 1996.

[20] B. S. Furniss, A. J. Hannaford, P. W. G. Smith, and A. R. Tatchell, Vogel's Text Book of Practical Organic Chemistry, Longman, London, UK, 5th edition, 1989.

[21] H. Mueller, M. U. Kassack, and M. Wiese, "Comparison of the usefulness of the MTT, ATP, and calcein assays to predict the potency of cytotoxic agents in various human cancer cell lines," Journal of Biomolecular Screening, vol. 9, no. 6, pp. 506-515, 2004.

[22] V. K. Chityala, K. S. Kumar, N. J. P. Subhashini, P. Raghavaiah, and Shivaraj, "Synthesis, crystal structure, spectroscopic, and biological studies on $\mathrm{Cu}$ (II) complexes of N,O donor dimethyl isoxazole Schiff bases," Journal of Coordination Chemistry, vol. 66, no. 2, pp. 274-286, 2013.

[23] E. Canpolat, "Studies on mononuclear chelates derived from substituted Schiff bases ligands (part 8): synthesis and characterization of a new 5-chlorosalicyliden-p-aminoacetophenoneoxime and its complexes with $\mathrm{Co}(\mathrm{II}), \mathrm{Ni}(\mathrm{II})$, $\mathrm{Cu}(\mathrm{II})$ and $\mathrm{Zn}(\mathrm{II})$," Polish Journal of Chemistry, vol. 79, no. 4, pp. 619-625, 2005.

[24] A. A. Soliman and W. Linert, "Investigations on new transition metal chelates of the 3-methoxy-salicylidene-2aminothiophenol Schiff base," Thermochimica Acta, vol. 338, no. 1-2, pp. 67-75, 1999.

[25] N. Raman, A. Kulandaisamy, C. Thangaraja, P. Manisankar, S. Viswanathan, and C. Vedhi, "Synthesis, structural characterisation and electrochemical and antibacterial studies of Schiff base copper complexes," Transition Metal Chemistry, vol. 29, no. 2, pp. 129-135, 2004.

[26] T. Rosu, S. Pasculescu, V. Lazar, C. Chifiriuc, and R. Cernat, "Copper(II) complexes with ligands derived from 4-amino-2,3dimethyl-1- phenyl-3-pyrazolin-5-one: synthesis and biological activity," Molecules, vol. 11, no. 11, pp. 904-914, 2006.

[27] E. Canpolat and M. Kaya, "Studies on mononuclear chelates derived from substituted Schiff bases ligands (part 3): synthesis and characterization of a new 5-nitrosalicylidene- $p$ aminoacetophenoneoxime and its complexes with $\mathrm{Co}(\mathrm{II})$, $\mathrm{Ni}(\mathrm{II}), \mathrm{Cu}(\mathrm{II})$, and $\mathrm{Zn}(\mathrm{II})$," Russian Journal of Coordination Chemistry, vol. 31, no. 6, pp. 415-419, 2005.

[28] A. Saxena and J. P. Tandon, "Structural features of some organotin(IV) complexes of semi- and thio-semicarbazones," Polyhedron, vol. 3, no. 6, pp. 681-688, 1984.

[29] P. Bamfield, "The reaction of cobalt halides with $N$ arylsalicylideneimines," Journal of the Chemical Society A: Inorganic, Physical, and Theoretical Chemistry, pp. 804-808, 1967.

[30] M. R. Maurya and C. Gopinathan, "Synthesis and characterization of dioxotungsten(VI) and dioxomolybdenum(VI) complexes of $\mathrm{N}$-isonicotinamido-o-hydroxyacetophenoneimine via their oxoperoxo complexes," Indian Journal of Chemistry A: Inorganic, Physical, Theoretical and Analytical Chemistry, vol. 35, no. 8, pp. 701-703, 1996.

[31] J. Viroopakshappa and D. V. Rao, "Synthesis and characterization of cobalt(II), nickel(II) and copper(II) chelates of ydroxy5-chlorobenzylideneamino)-5-methylisoxazole and hydroxy-5bromobenzylideneamino)-5-methylisoxazole," Journal of the Indian Chemical Society, vol. 73, no. 10, pp. 531-535, 1996.

[32] G. G. Mohamed, M. M. Omar, and A. M. M. Hindy, "Synthesis, characterization and biological activity of some transition metals with Schiff base derived from 2-thiophene carboxaldehyde and aminobenzoic acid," Spectrochimica Acta A: Molecular and Biomolecular Spectroscopy, vol. 62, no. 4-5, pp. 1140-1150, 2005.

[33] A. S. Aswar, A. D. Bansod, S. R. Aswale, P. R. Mandlik, C. Lage, and A. J. Costa-Filho, "Synthesis, characterisation, electrical and biological studies of $\mathrm{Cr}(\mathrm{III}), \mathrm{Mn}(\mathrm{III}), \mathrm{Fe}(\mathrm{III})$, $\mathrm{Ti}(\mathrm{III}), \mathrm{VO}(\mathrm{IV}), \mathrm{Th}(\mathrm{IV}), \mathrm{Zr}(\mathrm{IV})$ and $\mathrm{UO}_{2}(\mathrm{VI})$ polychelates with bis-bidentate Schiff base," Indian Journal of Chemistry A, vol. 43, pp. 1892-1896, 2004.

[34] P. R. Reddy and A. Shilpa, "Oxidative and hydrolytic DNA cleavage by $\mathrm{Cu}(\mathrm{II})$ complexes of salicylidene tyrosine Schiff base and 1,10 phenanthroline/bipyridine," Polyhedron, vol. 30, no. 4, pp. 565-572, 2011.

[35] E. Colacio, C. López-Magaña, V. McKee, and A. Romerosa, "Novel square-planar cyclic tetranuclear copper(II) complex containing oximate bridges. Synthesis, crystal structure and magnetic properties of tetrakis[diaqua( $\mu$-1,3-dimethylviolurato)-copper(II)] tetraperchlorate dihydrate," Journal of the 
Chemical Society-Dalton Transactions, no. 17, pp. 2923-2926, 1999.

[36] R. Srinivasan, I. Sougandi, R. Venkatesan, and P. Sambasiva Rao, "Synthesis and room temperature single crystal EPR studies of a dinickel complex having an $\mathrm{Ni}_{2}(\mu \text {-phenoxide })_{2}{ }^{2+}$ unit supported by a macrocyclic ligand environment $\left[\mathrm{Ni}_{2}(\mathrm{~L})_{2}\left(\mathrm{OClO}_{3}\right)_{2}\right]$ [L = 2-[(4-methyl-pyridin-2-ylimino)-methyl]-phenol] ," Journal of Chemical Sciences, vol. 115, no. 2, pp. 91-102, 2003.

[37] K. B. Patel, G. J. Kharadi, and K. S. Nimavat, "Synthesis and description of transition metal complexes and antimicrobialstudies," Journal of Chemical and Pharmaceutical Research, vol. 4, no. 5, pp. 2422-2428, 2012.

[38] K. B. Patel and K. S. Nimavat, "Synthesis, characterization and antimicrobial activity of transition metal complexes of 5-(propoxymethyl-8-quinolinol) (PMQ)," Der Chemica Sinica, vol. 3, no. 3, pp. 677-682, 2012.

[39] B. P. Ketan, M. P. Yogesh, and B. P. Raksha, "The metal complexes of 5-[(benzyloxy) methyl] quinolin-8-ol (BeMQ) and 8quinolinols mixed ligand: a new transition metal complexes with in-vitro antifungal activity," Research Journal of Recent Sciences, vol. 2, pp. 55-60, 2013.

[40] S. Panda, R. Mishra, A. K. Panda, and K. C. Satpathy, "Transition metal complexes with 4-amino-5-mercapto-3-methyl1,2,4-triazole and 8-hydroxyquinoline," Journal of the Indian Chemical Society, vol. 66, no. 7, pp. 472-474, 1989.

[41] D. Kivelson and R. Neiman, "ESR line shapes in glasses of copper complexes," The Journal of Chemical Physics, vol. 35, no. 1, pp. 149-155, 1961.

[42] J. Sanmartín, M. R. Bermejo, A. M. Garía-Deibe, M. Maneiro, C. Lage, and A. J. Costa-Filho, "Mono- and polynuclear complexes of $\mathrm{Fe}(\mathrm{II}), \mathrm{Co}(\mathrm{II}), \mathrm{Ni}(\mathrm{II}), \mathrm{Cu}(\mathrm{II}), \mathrm{Zn}(\mathrm{II})$ and Cd(II) with N,N'-bis(3-hydroxysalicylidene)-1,3-diamino-2propanol," Polyhedron, vol. 19, no. 2, pp. 185-192, 2000.

[43] S. Chandra and L. K. Gupta, "Mass, IR, electronic and EPR spectral studies on transition metal complexes with a new tetradentate 12-membered new macrocyclic ligand," Spectrochimica Acta A: Molecular and Biomolecular Spectroscopy, vol. 60, no. 13, pp. 3079-3085, 2004.

[44] V. D. Mouchlis, T. M. Mavromoustakos, and G. Kokotos, "Molecular docking and 3D-QSAR CoMFA studies on indole inhibitors of GIIA secreted phospholipase $\mathrm{A}_{2}$," Journal of Chemical Information and Modeling, vol. 50, no. 9, pp. 15891601, 2010.

[45] N. Raman, A. Kulandaisamy, A. Shunmugasundaram, and K. Jeyasubramanian, "Synthesis, spectral, redox and antimicrobial activities of Schiff base complexes derived from 1-phenyl-2,3dimethyl-4-aminopyrazol-5-one and acetoacetanilide," Transition Metal Chemistry, vol. 26, no. 1-2, pp. 131-135, 2001.

[46] R. S. Srivastava, "Pseudotetrahedral Co(II), Ni(II) and Cu(II) complexes of $\mathrm{N}^{1}$-(O-chlorophenyl)-2-( $2^{\prime}, 4^{\prime}$-dihydroxyphenyl)2-benzylazomethine their fungicidal and herbicidal activity," Inorganica Chimica Acta, vol. 56, pp. L65-L67, 1981.

[47] A. Cukurovali, I. Yilmaz, H. Ozmen, and M. Ahmedzade, "Cobalt(II), copper(II), nickel(II) and zinc(II) complexes of two novel Schiff base ligands and their antimicrobial activity," Transition Metal Chemistry, vol. 27, no. 2, pp. 171-176, 2007.

[48] P. R. Reddy, A. Shilpa, N. Raju, and P. Raghavaiah, "Synthesis, structure, DNA binding and cleavage properties of ternary amino acid Schiff base-phen/bipy Cu(II) complexes," Journal of Inorganic Biochemistry, vol. 105, no. 12, pp. 1603-1612, 2011.

[49] M. Riha, J. Karlickova, T. Filipsky, and K. Macakova, "Novel method for rapid copper chelation assessment confirmed low affinity of D-penicillamine for copper in comparison with trientine and 8-hydroxyquinolines ," Journal of Inorganic Biochemistry, vol. 123, pp. 80-87, 2013.

[50] K. A. Kumar, K. L. Reddy, and S. Satyanarayana, "Synthesis, DNA interaction and photocleavage studies of ruthenium(II) complexes with 2-(pyrrole) imidazo-[4,5-f]-1,10phenanthroline as an intercalative ligand," Transition Metal Chemistry, vol. 35, no. 6, pp. 713-720, 2010. 

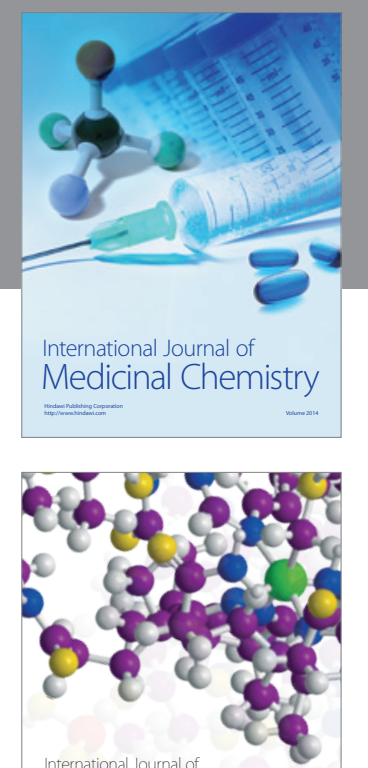

\section{Carbohydrate} Chemistry

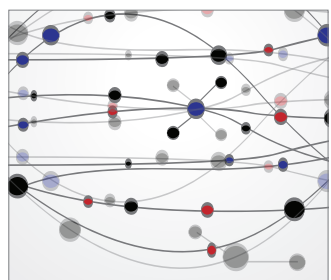

The Scientific World Journal
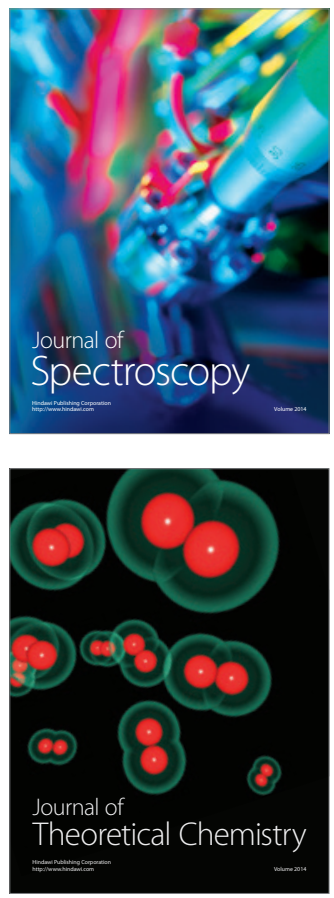
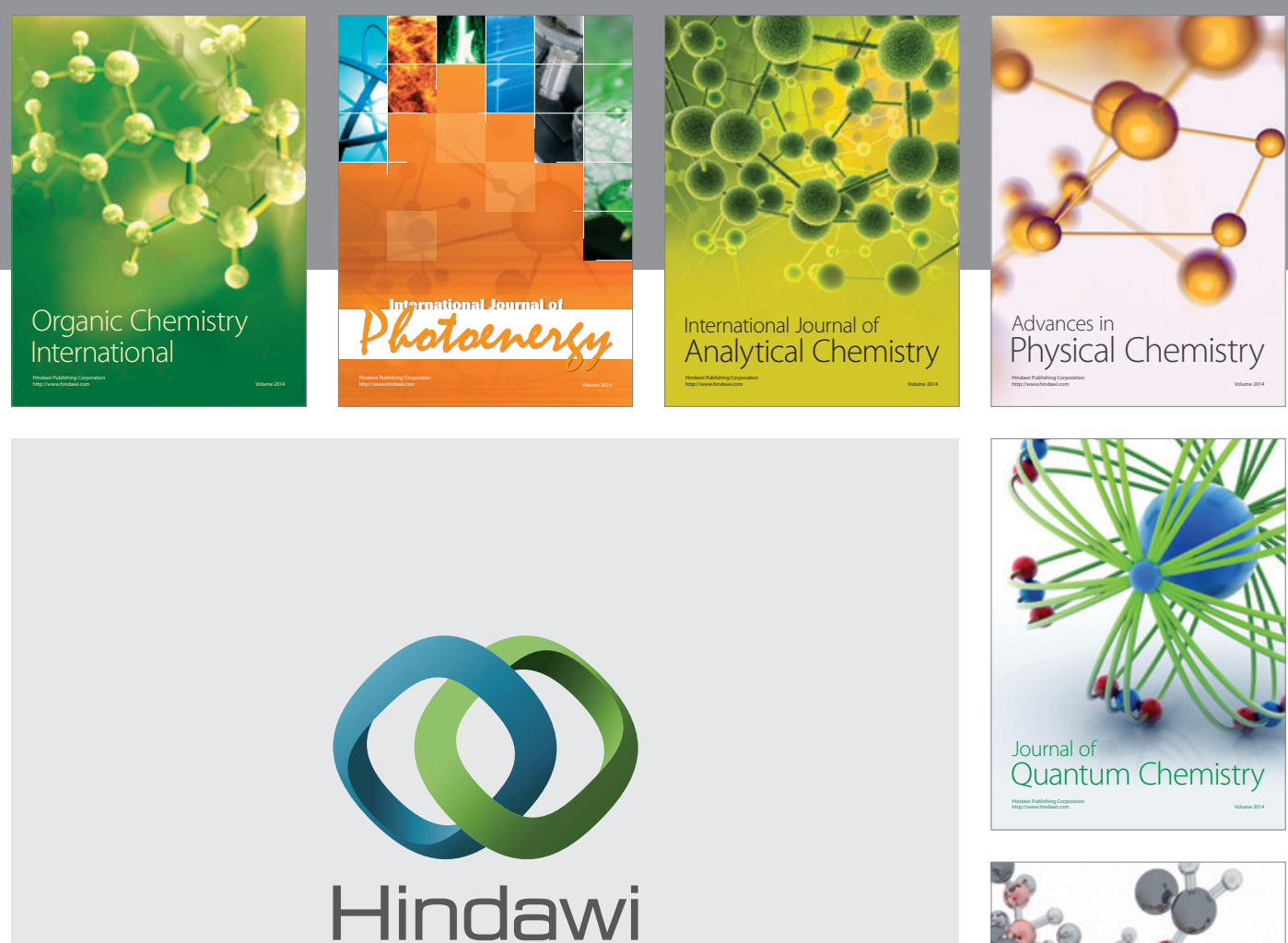

Submit your manuscripts at

http://www.hindawi.com

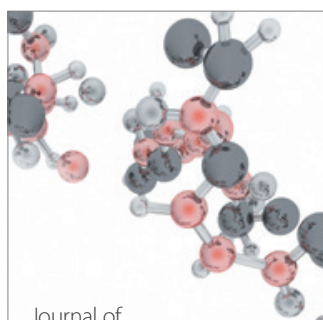

Analytical Methods

in Chemistry

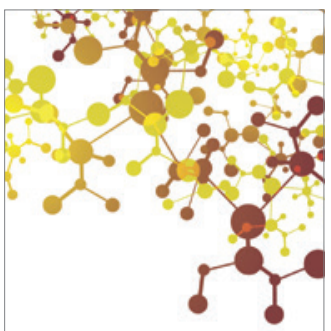

Journal of

Applied Chemistry

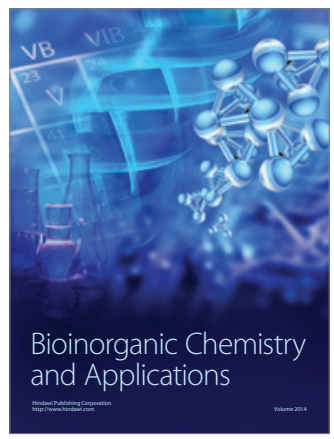

Inorganic Chemistry
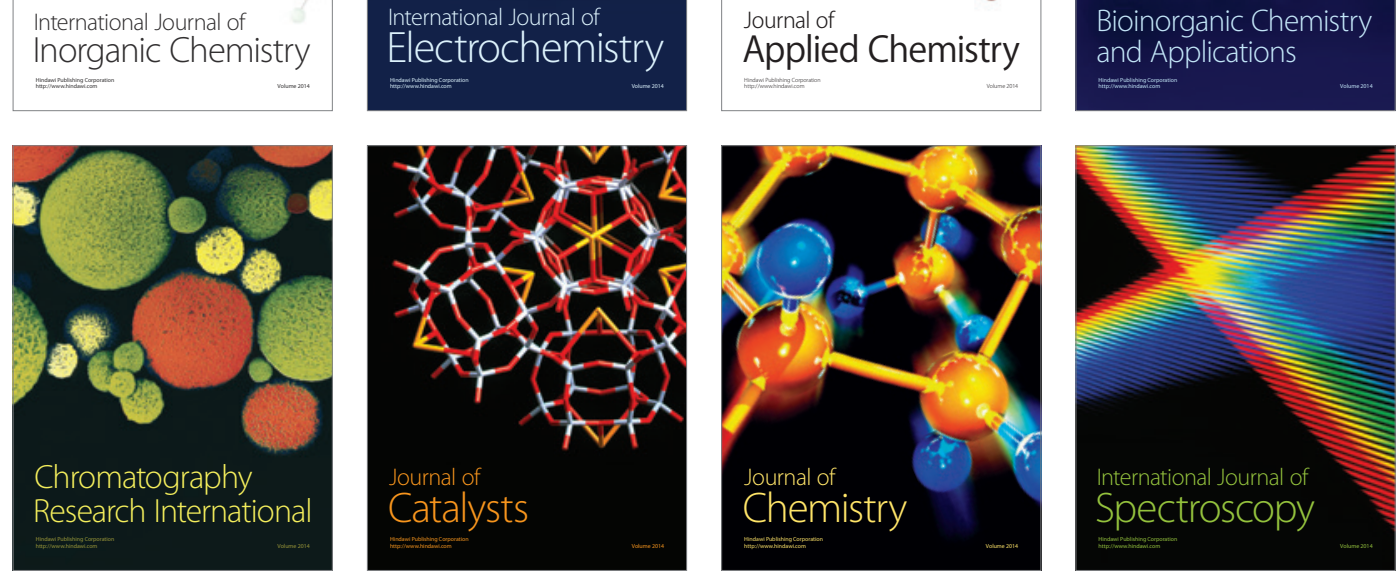